
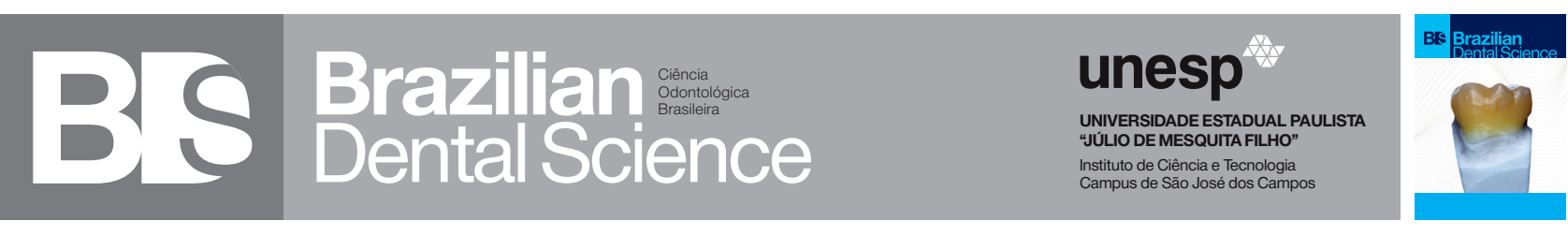

\title{
Behavioural perspective of tobacco use among youth of Vidarbha region of Maharashtra state in central part of India
}

Perspectiva comportamental do uso do tabaco entre jovens da região de Vidarbha, no estado de Maharashtra, na parte central da Índia

Gaikwad Rahul NARAYAN ${ }^{1}$

1 - Community Dentistry and Oral Epidemiology Department - College of Dentistry - Qassim University - Buraydah - Kingdom of Saudi Arabia.

\section{ABSTRACT}

Objective: this study was conducted to find out the youth perspective about the use of tobacco and its ill effects. The survey was conducted at a private Engineering college of Nagpur, Maharashtra India. Material and Methods: a cross-sectional study with self-administered modified Global youth tobacco survey (GYTS) questionnaire was used for data collection. Eight hundred nine college students of age group between 17 year-24years were included in this study. The questionnaire comprised of information on socio-demographic characteristics and questionnaire was used to gather data on knowledge, attitude and practices of participants about tobacco use. Data analysis was performed by using chi-square test and Statistical significance was measured at a level of 0.05. Results: out of 806 total participants, 136 (16.8) were current tobacco consumers, significantly high prevalence of tobacco use was observed among boys 106 (13.1) than girls 30 (3.7). Moreover, a higher number of boys 106 (13.1) started smoking at young adolescent age (13- 20 years) than girls30 (3.7). Conclusions: the findings in the study suggest that tobacco use is still an important risk behavior amongst students. Tobacco use was comparatively higher amongst boys though its use is not restricted to them only. There is a need to plan to gather nationwide baseline data on the use of tobacco by young adolescents and the factors associated with initiation of tobacco habit.

\section{KEYWORDS}

Global youth tobacco survey (GYTS); Tobacco prevalence; Tobacco use among youth.

\section{RESUMO}

Objetivo: Este estudo foi realizado para descobrir a perspectiva dos jovens sobre o uso do tabaco e seus efeitos nocivos. A pesquisa foi realizada em uma faculdade de engenharia privada de Nagpur, na Índia Maharashtra. Material e Métodos: Foi utilizado um estudo transversal com questionário autoadministrado de pesquisa global de tabaco juvenil modificado (GYTS) para coleta de dados. Oitocentos e nove estudantes universitários de faixa etária entre 17 e 24 anos foram incluídos neste estudo. Utilizou-se o questionário composto por informações sobre características sociodemográficas e para coleta de dados sobre conhecimentos, atitudes e práticas dos participantes em relação ao uso do tabaco. A análise dos dados foi realizada pelo teste do qui-quadrado e a significância estatística foi medida em um nível de 0,05. Resultados: Dos 806 participantes no total, $136(16,8)$ eram consumidores atuais de tabaco com prevalência significativamente mais alta entre os meninos $106(13,1)$ do que as meninas $30(3,7)$. Além disso, um número maior de meninos $106(13,1)$ começou a fumar na adolescência (13 a 20 anos) comparado ao número de meninas 30 (3,7). Conclusões: Os achados do estudo sugerem que o uso de tabaco ainda é um importante fator de risco comportamental entre os estudantes. O tabagismo foi comparativamente maior entre os meninos, embora seu uso não seja restrito apenas a eles. Há uma necessidade de planejar a coleta de dados de referência nacionais sobre o uso de tabaco por jovens adolescentes e os fatores associados ao início do hábito do tabagismo.

\section{PALAVRAS-CHAVE}

Pesquisa global sobre tabaco juvenil (GYTS); Prevalência de tabaco; Uso de tabaco entre os jovens. 


\section{INTRODUCTION}

$\mathrm{T}$ obacco use is one amongst the foremost necessary preventable causes of premature death, round the world. Tobacco use, primarily smoking, is a major preventable public health problem among the youth of the developing countries. Approximately 5 million people pass away every year due to tobaccorelated diseases and plenty of additional suffer from passive smoking-related morbidity [1]. Several studies have reported that youngsters smoke their 1st cigarette while attending school [2]. The tobacco consumption mainly smoking trend is higher among the males of developing countries, but in most developed countries is more shifted toward females $[3,4]$. In 1999 in the first World Health Organization (WHO) international conference on women and tobacco recognized tobacco use by females is a serious threat, growing downside throughout the world [5]. Various researches around the world reported higher prevalence of tobacco among the adolescent, in United Arab Emirates smoking prevalence among boys was $14.3 \%$ while it was 2.9 reported in girls. In a French study, smoking habit prevalence among male and females virtually same, $15.4 \%$ and $15.8 \%$ respectively. While in $27.8 \%$ of school children were regular smokers found in a Canadian schoolbased survey $[2,5]$.

The prevalence of smoking and tobacco use in India has been insufficiently revealed and it is varied contingent on location, traditions and religion. In Indian situation, grown-ups matured > 15 years' prevalence was accounted for $21 \%$ for cigarette smoking. In Rajasthan, the prevalence of smoking or tobacco consumption is $39 \%$ in urban men and $19 \%$ in urban females [3]. In Delhi, Mumbai smoking prevalence is found to be more among men (40\%) than for females $(10 \%$.) [3] While prevalence of tobacco consumption among central part of Indian rural women was $54.4 \%$ and in urban women was 40\% [6]. But there is a scarcity of literature on smoking and tobacco use among young adolescents. Few studies in India reported tobacco use among boys is more than girls in Goa, Mumbai, Delhi, Kerala and Jaipur [6-8]. The India Global youth tobacco survey among the age 13 to 15 years conducted in year 2009 showed, 19.0\% of boys and $8.3 \%$ of girls currently use any form of tobacco and $66.1 \%$ of them want to quit tobacco [9].

Directing the primary prevention action endeavors on youthful teenagers so as to enhance the general wellbeing in the close and far off future can be supported for a few interrelated reasons, for example, different health risk due to tobacco, liquor, and medication use, which are frequently adjusted to in growing adolescent. In the meantime, it might be less demanding to incorporate sound practices at a youthful age as opposed to adjusting the behavior at later ages or after the advanced stage of disease [8]. Open media ought to be utilized to feature and expanded about the risks of tobacco use and preventive strategies for youngsters. School tobacco program should become one of the powerful national methodologies to battle the hazardous burden of tobacco use among the young youth $[7,8]$. Hence this study was conducted to estimate the prevalence of tobacco use amongst college youth to evaluate the level of awareness regarding tobacco use and their practices towards it.

\section{MATERIAL AND METHODS}

A cross-sectional study was conducted at a private Engineering college of Nagpur, Maharashtra state, India. Eight hundred nine college students were included in this study. To be eligible participant, students should be between age group 17year-24years. The 
required permissions to conduct the study was taken from the concerned college authorities and after approval, the survey was carried out and written consent was obtained from the students who wanted to participate in the study. A self-administered modified Global youth tobacco survey (GYTS) questionnaire was used for data. Students were given a questionnaire in the classroom [5]. This questionnaire comprised of information on socio-demographic characteristics such as age, gender, year of study etc. questions designed to gather data on knowledge and attitude and practices of participants about tobacco use. The survey was administered during one class period. CDC- WHO designed procedures as the questionnaire itself is self-administered and the student's privacy was assured, and the care was taken to keep student's participation anonymous and voluntary. Students completed the questionnaire in the classroom, recording their response on the same sheet of the questionnaire. For the statistical analysis of the data Statistical Package for the Social Sciences (SPSS), version 11.5 software package was used. Chi-square test frequencies and cross-tabulation of the data was performed. Fishers exact test was used to analyze the significance difference among the gender. Statistical significance was measured at a level of 0.05 .

\section{RESULTS}

A cross-sectional study was conducted among engineering students at a private Engineering college of Nagpur, (Maharashtra) India from the year September 2014 to February 2015. Out of 2000 engineering students, 809 students responded (40.4) which includes 499 boys and 310 girls and of an age group of 17 years-24years. Analysis of data collected from respondent reflected in Table 1. Out of 809 total participants, 136 (16.8) were current tobacco consumers. Significantly high prevalence of tobacco consumption was found among boys 106 (13.1) than girls 30 (3.7). The prevalence of smoking was found to be more 74 (9.1) than a smokeless form of tobacco 62 (7.7). It has been observed that 128 (15.8) participants reported ever use of cigarette smoking, out of which prevalence among boys 108 (13.3) was significantly high compared to girls 20(2.5). Significantly higher number of boys 44 (5.4) said they would probably smoke if offered by their best friends compared to girls $2(0.2)$. Moreover, higher number of boys 24 (3.0) think smoking or chewing tobacco makes boys look more attractive than girls 16 (2.0) but no significant difference was recorded for this fact. (Table 1). 
Table 1 - Behavioural Perspective of tobacco use among study participants

\begin{tabular}{|c|c|c|c|c|}
\hline $\begin{array}{l}\text { Question/ } \\
\text { Response }\end{array}$ & Male & Female & Total & Significance \\
\hline Age & $\begin{array}{c}19.93 \pm 1.34 \\
(499)\end{array}$ & $\begin{array}{c}19.55 \pm 1.20 \\
(310)\end{array}$ & $809(100)$ & - \\
\hline \multicolumn{5}{|c|}{ 1. Tobacco consumer } \\
\hline Yes & $106(13.1)$ & $30(3.7)$ & 136(16.8) & \multirow{2}{*}{0.000} \\
\hline No & $393(48.6)$ & $280(34.6)$ & $673(83.2)$ & \\
\hline \multicolumn{5}{|c|}{ 2. Form of tobacco use } \\
\hline Cigarette & $66(8.2)$ & $8(1.0)$ & $74(9.1)$ & \multirow{3}{*}{0.000} \\
\hline Chew & $40(4.9)$ & $22(2.7)$ & $62(7.7)$ & \\
\hline $\begin{array}{l}\text { Not Appli- } \\
\text { cable }\end{array}$ & $393(48.6)$ & $280(34.6)$ & $673(83.2)$ & \\
\hline \multicolumn{5}{|c|}{ 3. Age of ${ }^{\mathrm{st}}$ use of tobacco product (in years) } \\
\hline $0-12$ & $44(5.4)$ & $12(1.5)$ & $56(6.9)$ & \multirow{4}{*}{0.000} \\
\hline $13-20$ & $52(6.4)$ & $18(2.2)$ & $70(8.6)$ & \\
\hline $21-40$ & $07(0.9)$ & $03(0.4)$ & $10(1.3)$ & \\
\hline Not applicable & $393(48.6)$ & $280(34.6)$ & $673(83.2)$ & \\
\hline \multicolumn{5}{|c|}{ 4. Ever use of tobacco in past } \\
\hline Yes & $108(13.3)$ & $20(2.5)$ & $128(15.8)$ & \multirow{2}{*}{0.000} \\
\hline No & $391(48.3)$ & $290(35.8)$ & $681(84.2)$ & \\
\hline \multicolumn{5}{|c|}{ 5. Presence of Friend or spouse tobacco use } \\
\hline Yes & $62(7.7)$ & $27(3.3)$ & $89(11.0)$ & \multirow{2}{*}{0.107} \\
\hline No & $437(54.0)$ & $283(35.0)$ & $720(89.0)$ & \\
\hline \multicolumn{5}{|c|}{$\begin{array}{l}\text { 6. If one of your best friends offered you a cigarette or a bidi or chewing } \\
\text { tobacco, would you take it? }\end{array}$} \\
\hline Definitely not & $391(48.3)$ & 291(36.0) & $682(84.3)$ & \multirow{4}{*}{0.000} \\
\hline Probably not & $48(5.9)$ & $17(2.1)$ & $65(8.0)$ & \\
\hline Probably yes & $44(5.4)$ & $2(0.2)$ & $46(5.7)$ & \\
\hline Definitely yes & $16(2.0)$ & $0(0.0)$ & $16(2.0)$ & \\
\hline \multicolumn{5}{|c|}{$\begin{array}{l}\text { 7. Do you think smoking or chewing tobacco makes boys look more attrac- } \\
\text { tive or less attractive? }\end{array}$} \\
\hline $\begin{array}{l}\text { More attrac- } \\
\quad \text { tive }\end{array}$ & $24(3.0)$ & $16(2.0)$ & $40(4.9)$ & \multirow{3}{*}{0.847} \\
\hline $\begin{array}{l}\text { Lessattrac- } \\
\quad \text { tive }\end{array}$ & $327(40.4)$ & $197(24.4)$ & $524(64.8)$ & \\
\hline $\begin{array}{l}\text { No difference } \\
\text { from Non-s- } \\
\text { mokers }\end{array}$ & $148(18.3)$ & $97(12.0)$ & $245(30.3)$ & \\
\hline \multicolumn{5}{|c|}{ 8. Per day use of chewing tobacco } \\
\hline 1/4th of tin & $18(2.2)$ & $7(0.9)$ & $25(3.1)$ & \multirow{4}{*}{0.000} \\
\hline $1 / 2$ of tin & $2(0.2)$ & $12(1.5)$ & $14(1.7)$ & \\
\hline 1or more tin & $24(3.0)$ & $5(0.6)$ & $29(3.6)$ & \\
\hline Not applicable & $455(56.2)$ & $286(35.4)$ & $741(91.6)$ & \\
\hline \multicolumn{5}{|c|}{ 9. Number of Packs of cigarettes consumption per day } \\
\hline $0-1 / 2$ & $23(2.8)$ & $0(0.0)$ & $23(2.8)$ & \multirow{6}{*}{0.000} \\
\hline 1 & $1(0.1)$ & $0(0.0)$ & $1(0.1)$ & \\
\hline $2-3$ & $26(3.2)$ & $0(0.0)$ & $26(3.2)$ & \\
\hline $3+$ & $11(1.4)$ & $0(0.0)$ & $11(1.4)$ & \\
\hline $\begin{array}{l}\text { less than } 10 \\
\text { cigarettes a } \\
\text { week }\end{array}$ & $5(0.6)$ & $8(1.0)$ & $13(1.6)$ & \\
\hline Not applicable & $433(53.5)$ & $302(37.3)$ & $735(90.9)$ & \\
\hline
\end{tabular}

\begin{tabular}{|c|c|c|c|c|}
\hline \multicolumn{5}{|c|}{ 10. Period of smoking or using tobacco } \\
\hline past1month & 2(0.2) & $0(0.0)$ & $2(0.2)$ & \multirow{6}{*}{0.000} \\
\hline 6 months & $16(2.0)$ & $1(0.1)$ & $17(2.1)$ & \\
\hline $\begin{array}{l}6 \text { months }-12 \\
\text { months }\end{array}$ & $53(6.6)$ & $12(1.5)$ & $65(8.0)$ & \\
\hline $1-8$ years & $27(3.3)$ & $12(1.5)$ & $39(4.8)$ & \\
\hline $\begin{array}{l}\text { more than } 5 \\
\text { years }\end{array}$ & $8(1.0)$ & $5(0.6)$ & $13(1.6)$ & \\
\hline Not applicable & $393(48.6)$ & $280(34.6)$ & $673(83.2)$ & \\
\hline \multicolumn{5}{|c|}{$\begin{array}{l}\text { 11. Do you think cigarette smoking or chewing tobacco is harmful to your } \\
\text { health? }\end{array}$} \\
\hline Definitely not & $0(0.0)$ & $4(0.5)$ & $4(0.5)$ & \multirow{5}{*}{0.000} \\
\hline Probably not & $16(2.0)$ & $9(1.1)$ & $25(3.1)$ & \\
\hline Probably yes & $67(8.3)$ & $22(2.7)$ & $89(11.0)$ & \\
\hline Definitely yes & $392(48.5)$ & 273(33.7) & $665(82.2)$ & \\
\hline IDon'tknow & $24(3.0)$ & $2(0.2)$ & $26(3.2)$ & \\
\hline \multicolumn{5}{|c|}{ 12. Have you ever thought about quitting tobacco? } \\
\hline Yes & $42(5.2)$ & $11(1.3)$ & $53(6.5)$ & \multirow{3}{*}{0.000} \\
\hline No & $63(7.8)$ & $20(2.5)$ & $83(10.3)$ & \\
\hline Not applicable & $393(48.6)$ & $280(34.6)$ & $673(83.2)$ & \\
\hline \multicolumn{5}{|c|}{$\begin{array}{l}\text { 13. Once someone has started smoking or chewing tobacco, do you think } \\
\text { would be difficult to quit? }\end{array}$} \\
\hline Definitely not & $54(6.7)$ & $37(4.6)$ & $91(11.2)$ & \multirow{5}{*}{0.670} \\
\hline Probably not & $68(8.4)$ & $51(6.3)$ & $119(14.7)$ & \\
\hline Probably yes & $189(23.4)$ & $110(13.6)$ & $299(37.0)$ & \\
\hline Definitely yes & $110(13.6)$ & $60(7.4)$ & $170(21.0)$ & \\
\hline IDon'tknow & $78(9.6)$ & $52(6.4)$ & $130(16.1)$ & \\
\hline \multicolumn{5}{|c|}{ 14. Reason for quitting tobacco in past } \\
\hline Health & $36(4.5)$ & $1(0.1)$ & $37(4.6)$ & \multirow{5}{*}{0.670} \\
\hline Money & $1(0.1)$ & $10(1.2)$ & $11(1.3)$ & \\
\hline $\begin{array}{l}\text { Family/ Social } \\
\text { acceptability }\end{array}$ & $5(0.6)$ & $0(0.0)$ & $5(0.6)$ & \\
\hline Don’tknow & $63(7.8)$ & $20(2.5)$ & $83(10.3)$ & \\
\hline Not applicable & $393(48.6)$ & $280(34.6)$ & $673(83.2)$ & \\
\hline \multicolumn{5}{|c|}{ 15. Knowledge about "Tobacco Cessation Centres" (TCC)? } \\
\hline Yes & $99(12.2)$ & $56(6.9)$ & $155(19.2)$ & \multirow{2}{*}{0.533} \\
\hline No & $400(49.4)$ & $254(31.4)$ & $654(80.8)$ & \\
\hline \multicolumn{5}{|c|}{$\begin{array}{l}\text { 16. Would you like to register at "Tobacco Cessation Centre" (TCC) to help } \\
\text { you with your addiction? }\end{array}$} \\
\hline Yes & $42(5.2)$ & 10(1.2) & $52(6.4)$ & \multirow{2}{*}{0.003} \\
\hline No & $457(56.5)$ & $300(37.1)$ & $757(93.6)$ & \\
\hline \multicolumn{5}{|c|}{ 17. Knowledge aboutE-cigarettes? } \\
\hline Yes & $78(9.6)$ & $44(5.4)$ & $122(15.1)$ & \multirow{2}{*}{0.579} \\
\hline No & $421(52.0)$ & $266(32.9)$ & $687(84.9)$ & \\
\hline \multicolumn{5}{|c|}{ 18. What all methods you have tried to quit tobacco? } \\
\hline Exercise & $14(1.7)$ & $2(0.2)$ & $16(2.0)$ & \multirow{7}{*}{0.234} \\
\hline $\begin{array}{l}\text { Self-Motiva- } \\
\quad \text { tion }\end{array}$ & $16(2.0)$ & $5(0.6)$ & $21(2.6)$ & \\
\hline $\begin{array}{l}\text { Chewing } \\
\text { gums }\end{array}$ & $1(0.1)$ & $10(1.2)$ & $11(1.3)$ & \\
\hline other & $5(0.6)$ & $0(0.0)$ & $5(0.6)$ & \\
\hline Not tried & $63(7.8)$ & $20(2.5)$ & $83(10.3)$ & \\
\hline Not applicable & $393(48.6)$ & 280 (34.6) & $673(83.2)$ & \\
\hline Total & $499(61.7)$ & $310(38.3)$ & $809(100.0)$ & \\
\hline
\end{tabular}


In the present study, 44 (5.4), boys started smoking at a young adolescent age than 12 (1.5) girls. The majority of boys and girl's participants in the present study consume tobacco more than 6 months $\{53(6.6) ; 12$ (1.5)\} respectively. Further students were asked about the harmful effects of tobacco on their health and it was found that majority of boys 392 (48.5) and girls 273 (33.7) think that cigarette smoking or chewing tobacco is definitely harmful to health. Finally, students were asked question to evaluate tobacco quit behavior, 42 (5.2) boys and 11 (1.3) girls ever thought about quitting tobacco and 54 (6.7) boys and 37 (4.6) girls think it would be definitely not difficult to quit, whereas 110 (13.6) boys and 60 (7.4) girls think it is definitely difficult to quit. Out of total participants 654 (80.8) participates were not aware of tobacco cessation centers, but 78 (9.6) boys and 44 (5.4) girls have heard about E-Cigarettes as a mean for quitting tobacco habit. (Table 1)

\section{DISCUSSION}

The present study conducted among the youth of central part of India to gain an insight to their behavior toward tobacco use. Although majority of the youth were not tobacco consumer but their perspective toward tobacco use and knowledge about quitting cannot be overlooked. Tobacco use in young people is achieving pandemic dimensions. This is particularly pertinent for the developing nations like India, where tobacco use keeps on being normal despite the acknowledgment of unsafe results of its utilization. Considering the tremendous complications related to tobacco use, it is of most extreme significance to comprehend the factors prompting its utilization and to design methodologies to diminish its intake. The most vital factor for tobacco use is the totality of industrial action, including publicizing and promoting, authoritative movement and political activity, which keeps up the attractiveness and profitability of the tobacco items. The data reported here demonstrate the current status of the tobacco epidemic among young youth of India. Comparisons with earlier GYTS data from various studies suggest that tobacco use is a rising health problem among adolescents [9-12]. Out of 809 participants, 136 (16.8\%) were regular Tobacco consumer, 74 (9.1) were smokers and 62 (7.7) of them were using smokeless form of tobacco Which is similar to study done by $\mathrm{K}$. Mukherjee and Hadaye [11] and Kyrlesi and Steriades [12] in 2007 reported overall smokeless tobacco use as $10 \% \& 10.9 \%$ respectively. In the GYTS 2003 and 2006 [13], the prevalence of any form of tobacco use was $16.9 \%$, and 14.1 respectively, which is higher than the present study. According to Srinath Reddy \& Prakash Gupta [14] GYTS 2002-2004, 14.6\% were the current smokeless tobacco users ranging from $2 \%$ in Himachal Pradesh to 55.6\% in Bihar. In present study 128 (15.8\%) participants reported ever use of cigarette smoking, which is in line with study by Thakappan and Thresia [15] in Kerala in 2007, the prevalence of ever use of cigarette was $13.6 \%$, in a study by Sreeramareddy and Kishore [16] in 2007 in Nepal ever user was $13.9 \%$, Chadda R K and Sengupta [17] reported $14.1 \%$ and in Karachi by Rozi and Akthar [18] in 2007, the prevalence of smoking was $13.7 \%$. While GYTS 2003 and 2006 [13] showed lower prevalence of ever use of tobacco $9.5 \%$ and $12 \%$ respectively. However, a study in Uganda in 2004 by Mpabulungi and Muula [19] found $17.5 \%$ which was higher than the present study. According to Fishers exact test gender wise prevalence among boys 106 (13.1) was significantly high compared to girls 30 (3.7) in present study which was found to be similar to study by Sreeramareddy and Kishore [15] in 2007 in Nepal boys (19.2\%) girls (4.4\%) and GYTS 2009 (Boy $=19.0 \%$, Girl = 8.3\%.) [9]. Whereas, Tiwari RV et.al. reported exceptionally high tobacco use in rural women (54.4\%) than in urban women (40\%) [6].

In the present study, significantly higher 
number of boys 52 (6.4) compared to girls 18 (2.2) started smoking at young adolescent age (13 - 20 years). According to Narain et.al 2011 [20], the mean age of initiation of tobacco use has been found to vary from 8 to 15 years. The majority of the tobacco users worldwide have reportedly the tobacco prior to age 18 years, some starting as young as 10 years [12]. However Peterson et al. [21] reported cigarette smoking seems to peak at the ages from 18 - 24 years. In the Kerala study, the mean age at initiation was 10.7 year for boys $\leq 13$ years and 13.2 years for girls $\geq 16$ years at the time of survey [14]. According to GYTS central 2003 and 2006 Percentage of Smoking initiation before the age of 10 was found to be high 13.7 and 24 respectively [13]. The harmful effect of Tobacco was assessed among study participants, 392 (48.5) boys and 273 (33.7) girls think cigarette smoking or chewing tobacco is definitely harmful to health. In GYTS 2002 in Uttaranchal [13] 60.2\% of students agreed that smoking or chewing tobacco is definitely harmful to them. Whereas Trivedi and Zachariah [22] reported that $68 \%$ of boys and $94 \%$ of girls were aware of the harms of tobacco. Similarly, Rameshwar and Pednekar [23] reported that $78.4 \%$ were aware of the serious health risks associated with tobacco use. However, V. Singh and R. Gupta [3] reported that $99.2 \%$ of the boys and $9.5 \%$ of the girls were aware of the harmful effects of tobacco. The quitting prevalence of tobacco was recorded and it was found that 42 (5.2) boys and 11 (1.3) girls ever thought about quitting tobacco. Srinath Reddy \& Prakash Gupta [14] GYTS 2002-2004 reported 71.4\% had tried to quit in the past year. However, in a study by Madan Kumar and Poorni [24] in Chennai in $200653.6 \%$ of the current smokers had already tried to quit in the past year. In a study done in Greece by Kyrlesi and Steriades [12] in 2007, $49.1 \%$ of the current smokers had already tried to quit in the past year which is similar to the present study. In a study in Uganda by Mpabulungi and Muula[19] 76.9\% of the current smokers had already tried to quit in the past year. Present study revealed that $654(80 \%)$ participants were not aware about tobacco cessation centers but in a study done in Uganda by Mpabulungi and Muula19 in 2007, 84.1\% current smokers reported that they had received help to quit the habit. However, in the study by Sreeramareddy and Kishore [16] in 2007 in Nepal, 55.3\% current smokers reported that they had received help to quit the habit.

\section{CONCLUSION}

The findings in the study suggest that tobacco use among youngsters is still an essential risk behavior. It has been observed that tobacco use was comparatively higher amongst boys however its utilization isn't confined to them as it were. It has been observed that participants were willing to quit but they don't know about tobacco centers. Besides, knowledge about tobacco quit alternatives like E-cigarettes is found to be less. The present study finding provides insight to the total burden of tobacco among the central part of the youth and their knowledge and practice related to tobacco use but the response about the tobacco use was depended on self-reported data. There is a need to collect nationwide data on the use of different forms of tobacco use involving larger sample size among young youth and the variables prompting the inception of such destructive propensities.

\section{REFERENCES}

1. Bahaj AA, Baamer AA, Bin Briek AS. Prevalence of tobacco use among young students in Yemen. JBahrain Med Sc. 2010;22(1):5-8.

2. Muttappallymyalil J, Divakaran B, Thomas T, Sreedharan J, Haran JC. Thanzeel M. Prevalence of tobacco use among adolescents in India. Asian Pacific J Cancer Prev. 2012;13(11):5371-4.

3. Singh V, Gupta R. Prevalence of Tobacco Use and Awareness of Risks among School Children in Jaipur. J Assoc Physicians India. 2006 Aug;54:609-12.

4. Gaikwad R, Bhowate R, Bajad P, Gadbail AR, Gondivkar S, Sarode SC, et al. Potential predictor of tobacco cessation among factory workers: a baseline data of worksite tobacco cessation programs in the central part of India. J Contemp Dent Pract. 2017 Nov 1;18(11):1071-7.

5. IAwa F, Fouad H, El Naga RA, Emam AH, Labib S. Prevalence of tobacco use among adult and adolescent females in Egypt. East Mediterr Health J. 2013 Aug;19(8):749-54. 
6. Tiwari RV, Gupta A, Agrawal A, Gandhi A, Gupta M, Das M. Women and Tobacco Use:Discrepancy in the Knowledge, Belief and Behavior towards Tobacco Consumption among Urban and Rural Women in Chhattisgarh, Central India. Asian Pac J Cancer Prev. 2015;16(15):6365-73.

7. Singh V,Pal HR, Mehta M, Kapil U. Tobacco consumption and awareness of their health hazards amongst lower income group school children in National Capital Territory of Delhi. Indian Pediatr.2007 Apr;44(4):293-5.

8. Thekdi KP, Kartha GP,Purani SK, Nagar SS. A study on the prevalence of use of tobacco amongst school going children (11 to 15 years age group) of Surendranagar. Healthline. 2013;4(1):43-9.

9. India (Ages 13-15); Global Youth Tobacco Survey (GYTS). Avaiable at: http:// www.searo.who.int/entity/noncommunicable_diseases/data/ind gyts fs_2009.pdf?ua01. Accessed 2019/Apr/18.

10. Khan SA, Bilal S, Askari J,Nathani A, Mohsin SF. The prevalence of tobacco consumption in youth of Karachi, Pakistan - a pilot study. Biomedica. 2009;25:166-70.

11. Mukharjee K, Hadaye RS. Gutka consumption and its determinants among secondary school male students. Indian J Community Med. 2006:31(3):177.

12. Kyrlesi A, Soteriades ES, Warren CW, Kremastinou J, Papastergiou P, Jones NR, Hadjichristodolou C. Tobacco use among students aged 13-15 years in Greece: the GYTS project. BMC Public Health. 2007 Jan 8;7:3.

13. Sinha DN. Tobacco Control in Schools in India (India Global Youth Tobacco Survey \& Global School Personnel Survey, 2006) Avaiable at: http://www. searo.who.int/entity/noncommunicable diseases/data/ind gyts fs 2009 . pdf?ua01 Accessed on April 18, 2019.

14. Reddy KS, Gupta PC. Report on Tobacco Control in India. Ministry of Health and Family Welfare, Government of India. New Delhi. 2004.
15. Thankappan KR Thresia CU. Tobacco use \& social status in Kerala Indian J Med Res. 20070ct;126(4):300-8.

16. Sreeramareddy CT, Kishore P,Paudel J,Menezes RG. Prevalence and correlates of tobacco use amongstjunior collegiates in twin cities of western Nepal: a cross-sectional, questionnaire-based survey. BMC Public Health. 2008 Mar 26;8:97. doi:10.1186/1471-2458-8-97.

17. Chadda RK, Sengupta SN. Tobacco use by Indian adolescents tobacco induced diseases. Tob Induc Dis. 2002 Jun 15;(2):111-9. doi: 10.1186/1617-9625-1-2-111.

18. Rozi S, Akhtar S. Prevalence and predictors of smokeless tobacco use among high-school males in Karachi, Pakistan. East Mediterr Health J. 2007 JulAug;13(4):916-24.

19. Mpabulungi L, Muula AS. Tobacco use among high school students in Kampala, Uganda: questionnaire study. Croat Med J. 2004 Feb;45(1):80-3.

20. Narain R, Sardana S, Gupta S, Sehgal A. Age at initiation \& prevalence of tobacco use among school children in Noida, India: A cross-sectional questionnaire based survey. Indian J Med Res. 2011 Mar;133:300-7.

21. PetersonE, Fenaughty A, Eberhart-Phillips JE, Tobacco in the Great Land, A Portrait of Alaska's Leading Cause of Death. Anchorage, AK: Section of Epidemiology, Division of Public Health, Alaska Department of Health and Social Services, 2004.

22. Krishnamurthy S, Ramaswamy R, Trivedi U,Zachariah V. Tobacco use in rural Indian children. Indian Pediatr. 1997 0ct;34(10):923-7.

23. Sharma R, Pednekar MS, Rehman AU, Gupta R. Tobacco use among school personnel in Rajasthan, India. Indian JCancer.2004 0ct-Dec;41(4):162-6.

24. Kumar M, Poorni S, Ramachandran S. Tobacco use among school children in Chennai city, India Indian J Cancer.2006 Jul-Sep;43(3):127-31.

\section{Dr. Gaikwad Rahul N.}

(Corresponding address)

Plot No. 67, Yogiraj Colony, Tapowan, New Camp Area, Amravati - 444602

Maharashtra, India.

Email: dr.rahul.gaikwad@qudent.org 